\title{
Vem möter du på bussen?
}

\section{Av Bärbel Westphal, universitetsadjunkt i tyska}

\author{
Länk till presentation av Bärbel Westphal
}

\section{I}

Det vet man ju, hur de är! Högljudda, stökiga. Ska säkert börja gräla med någon i bussen. Och lukten sen. Medan jag med en lätt anstrykning av huvudvärk stint ser ut genom fönstret, går han - gudskelov - förbi mig till platsen bakom. Jaha, det ante mig. Alltid skall de ge sig på de yngre tjejerna som är alldeles för snälla för att säga ifrån. "Offret" i fråga kan vara 19-20, ser ut som 16-17. Hon har vackert brunt hår, liljevit hy och ganska intellektuella glasögon. Hon verkar snäll i alla fall.

- Du ser ju förståndig ut! säger den på busslinjen välkände 50-åringen. Han själv är ganska mager, tärd av livsstilen, men med livliga ögon. Håret är grått nu. Han var nog en gång en riktig charmör. Jag stönar inombords. Nu skall han alltså börja munhuggas med flickan. Jag kastar en uppmanande och moderligt forskande blick på henne.

\section{II}

- Finns det oskyldiga människor? frågar han henne.

- Tja, barnen är väl det, säger hon.

- Men synden då?

- Vilken synd?

- Jo,arvssynden! Du förstår, har du syndiga föräldrar, då föds du med skuld!

Hon skrattar.

- Och det tror du på? Alltså, jag vet vad du menar, men jag tror inte på bibeln. Eftersom Gud inte har skrivit den utan människor, så är det inte Guds ord!

- Nehe. Då är du inte kristen?

- Tja, lägger hon ut, jag var med i frälsningsarmén en gång och det var skoj, för jag var scout. Men när jag skulle konfirmeras tog jag beslutet att gå ur. Jag tyckte att man inte kunde veta om Gud finns.

- Du har alltså inte mött Gud eller Jesus?

- Nej, men jag har många frälsta vänner som påstår sig ha gjort det. Har du?

- Ja, flicka lilla, det har jag. Det var i Malmö en gång, då träffade jag Jesus. Men, ser du, det hjälper inte alltid en människa att ha gjort det.

\section{III}

- Förresten, vad heter du?

- Heidi.

- Vet du vad det betyder?

- Jo, nej, det har jag glömt.

- Då vet du egentligen inte vad du heter. Jag heter Bengt och det betyder "den helige".

- Jag tycker inte att du verkar speciellt helig, om jag får säga så.

- Nej, jag har nog många gånger varit orättvis mot mina vänner.

- Ja, det är lätt hänt, tycker hon medkännande. Och nu kom jag på vad Heidi betyder: "litet moln"- eller så.

- Oj då, säger han, då skymmer du ju solen!

- Nja, men jag är bara ett l i t e t moln! 
- Läser du bibeln någon gång? forskar han vidare.

- Nej, jag måste medge att jag inte har gjort det och det skäms jag för.

- Då vet du ju inte heller vad du pratar om. Vad läser du annars?

- Jag skall läsa bibeln. Jag lovar. Just nu läser jag på högskolan om vetenskap och samhälle.

- O.K., då har du läst fransmän som Sartre eller tyskar som Heidegger!

- Neej, inte det heller, medger hon.

- Nå, då tycker jag att du åtminstone börjar läsa Timoteus eller Paulus brev! Annars får man ju inte läsa andras brev, ha ha, säger han, medan hon reser sig för att stiga av.

- Timoteus, upprepar hon, ja visst, det skall jag läsa! Ha en bra dag!

\section{V}

Jag stirrar fortfarande ut ur fönstret. Denna gång för att känslorna är starka. Jag skäms. Vad är en god människa? Hösten därute lyser. Sådana här samtal vill jag höra fler på bussen! Bengt ställer sig bredbent i gången, ler och slår ut med armarna:

- Så, mina damer, vilken vacker dag!

Vi är bara två kvar förutom han.

- Jaa, säger jag, så underbara färger. Och tänker att jag just nu måste ha träffat en bit Gud som kunde värma mig så ända in i själen.

- De vackraste färger har ögon, säger Bengt, och nu skall jag slänga ut mina katter och vattna mina blommor, eller var det tvärtom? Skrattande studsar han ut från bussen.

\section{VI}

Under sista biten till min station stiger ett minne upp. Medan passagerarna drar sig illa berörda till den bakre delen av bussen - lukten ä r alltid det värsta, tar han där på första platsen fram ett munspel. Små trevande toner kommer och sedan forsande, bubblande, sprittande melodier! Hela Sveriges landsbygd dansar fram! Jag tar upp applåden, en efter en följer efter tills hela bussen applåderar.

- Tyckte ni om det? Då spelar jag en till!

När möter vi Gud på nittonhundranittiotalet? Samhällets skuggfigurer har skänkt mig två starka upplevelser, glans, färg och en tro på det goda på min resa genom vardagen.

(Artikeln även publicerad i Smålandsposten 971013) 